\title{
Tracing Tendencies in the Japanese Documentary Mode ${ }^{\dagger}$
}

\author{
Marcos P. Centeno-Martín ${ }^{1, *}$ (D) and Michael Raine ${ }^{2}$ \\ 1 Department of Cultures and Languages, School of Arts, Birkbeck, University of London, \\ London WC1E 7HX, UK \\ 2 Department of English and Writing Studies, Western University, London, ON N6A 3K7, Canada; \\ mraine3@uwo.ca \\ * Correspondence: m.centeno@bbk.ac.uk \\ + The Japanese names in this Special Issue follow the Japanese convention (family name first name).
}

Received: 29 July 2020; Accepted: 29 August 2020; Published: 21 September 2020

check for updates

\section{Introduction}

The documentary mode has not had the recognition it deserves in the western historiography of Japanese cinema. The 'discovery' of that cinema at film festivals in Europe and the United States in the 1950s, and the growth of academic and popular writing that followed, prioritized aesthetic and cultural difference and obscured Japan's contribution to the documentary mode. Canonical authors such as Donald Richie, who was instrumental in introducing Japanese cinema to the West, even claimed that Japan did not have a true documentary tradition due to the apparent preference of the Japanese audience for stylisation over realism, a preference that originated from its theatrical tradition (Richie 1990, p. 60). And yet, over 130,000 documentary films were made between 1945 and 2010 (Murayama 2010, pp. 240-46), and postwar Japanese documentary films regularly won prizes at specialist film festivals. ${ }^{1}$ Beyond documentary film production itself, a closer look at the history of Japanese feature film production also calls Richie's assertion into question. "Semi-documentary" and "documentary touch" were clichés of postwar feature film criticism, in response to a renewed emphasis on actuality and ordinary life in at least one strand of Japanese studio and independent production. This special issue, Developments in Japanese Documentary Mode, seeks to challenge the predominance of fiction film in the literature on Japanese cinema, and in particular the assumption of a stylised Japanese aesthetic. It reveals a broad sense in Japan of the film medium as connected to material and phenomenological authenticity, even as that rhetorical effect was sometimes put in service to political and economic ideologies.

As Bill Nichols has argued, film as "document" is an inherent power of this apparently automatic medium, visible in its early uses as a scientific recording apparatus, an exhibitionist purveyor of "attractions", and in the earliest actualities. But, Nichols continued, in order to become a genre, that documentary aspect of film had to be supplemented by the subjective intentionality of filmmakers (what John Grierson called the "creative treatment of actuality" (Grierson 1933, p. 8)). Those filmmakers crafted their material into stories, as part of a group of practitioners supported by institutions, making films that helped organize the ambitions of fellow filmmakers and the expectations of audiences. At the same time, that narrative aspect of documentary film opens the door to its apparent other: the fiction film. If documentary must employ storytelling in order to tell us about our world, the fiction film can draw on the documentary's "impression of authenticity" (Nichols 2017, p. xii) by foregrounding its material aspects of unglamourised people in real locations leading ordinary lives. Even Grierson

1 See The Educational Film Producers Association of Japan Inc. (ed). Short Films of Japan, bulletin of the Association for the Diffusion of Japanese Films Abroad. 
recognized the "documentary value" of the fiction film (Grierson 1979, p. 25). Rediscovering, organising, and assessing Japanese contributions to the documentary mode from narrative, aesthetic, and theoretical points of view, the articles in this special issue embrace the ambiguity of documentary as what Bill Nichols called a "fiction (un)like any other" (Nichols 2017, p. 4).

The scope of this special issue goes beyond documentary film alone. Rather than a distinct genre, the articles in this issue trace a "documentary mode" characterised by a rhetoric of truthfulness that, like Peter Brooks' influential "melodramatic mode" (Brooks 1976, p. 12), spans multiple media and genres. This tendency may operate in different formats, from newsreels to fiction films, from magic lanterns to television and can be observed in disciplines from film theory to folklore studies. In this sense, the selected articles interrogate documentary movements, schools, and ways of approaching reality, challenging the limiting understanding of documentary as a self-contained category and proposing a renewed framework for the study of "nonfiction film" that is not necessarily limited to "nonfiction" or even "film". Each article in this issue focuses on an aspect of documentary in Japan, from the intertextual grounding of the prewar culture film (bunka eiga) through theoretical debates in postwar documentary and developments in ancillary media, such as magic lantern images and photography, to the incorporation of the tension between objectivity and subjectivity, characteristic of documentary, into feature film production. In this introduction we provide some historical and theoretical context for the developments and debates presented in the articles. That history is necessarily incomplete, but rather than establish a single narrative line we hope that through these diverse articles, readers will gain an enhanced understanding of the history and possibilities of the documentary mode in Japan.

\section{Early Developments and Terminologies}

Since its inception, Japanese nonfiction and adjacent formats have evolved and adopted different terminologies. In fact, the literal translation of "documentary" in Japanese (dokyumentari or kiroku eiga) was neither the earliest nor the most common expression used in Japan until at least the end of World War II. The terminological confusion is compounded by shifts between media and ambiguities over the epistemological status of film images. Komatsu Hiroshi went so far as to argue that there was no conceptual distinction between fiction and nonfiction in the early period of Japanese filmmaking. The dominant form of early film drama, the so-called kyügeki, had such strong intertextual connections to the existing theatre that they were in some ways documents of a dramatic performance. On the other hand, films that supposedly showed conditions on the ground during the Russo-Japanese war of 1904-1905 regularly featured models and scenes restaged in Japan. Audiences only objected when the models and the staging were poor (Komatsu 1992).

The first nonfiction film in Japan can be found in the earliest moving images ever shot in the country. They were thirty-three sequences, dating back to 1897 and 1898, shot by August Lumière's French camera operators François-Constant Girel and Gabriel Veyre, as well as the Japanese apprentice Shibata Tsunekichi, using a cinematograph, which had been acquired by the industrialist Inabata Katsutarō (Koga 1995, pp. 31-43; Anderson and Donald 1982, p. 146; Nornes 2003b, pp. 2-3). The films were so-called "actualities", short sequences that proliferated during the first decades of the twentieth century, as they were cheaper and easier to produce than narrative fiction films, which required a script, actors, settings, and so on (Musser 1994, p. 232). Japanese entrepreneurs saw in these actualities a profitable business and developed a new nonfiction format, a sort of proto-newsreel called jiji eiga ("real-life movies") during the Boxer Rebellion (1898-1901). As in other countries, many of these proto-newsreels were "fabricated news films" (kōsei sareta nȳ̄su eiga), based on real events but re-enacted in studios, while others were directly "fake news films" (nise nyūsu eiga), completely fabricated events (Komatsu 1992, p. 238). By the 1910s nonfiction practices were re-evaluated based on new expectations of truthfulness, which were largely motivated by the emergence of permanent film theatres (Komatsu 1992). These venues replaced travelling troupes, and audiences began to regard 
cinema as a valuable source of information, rather than merely as entertainment (Greenberg 2001, p. 7), though that information was still often presented in the form of scripted and/or re-enacted scenes.

The rhetoric of truthfulness mentioned above not only evolved into these jiji eiga, but also into a more elaborate format, the travelogue or travel documentary in the 1910s. The American entrepreneur William Selig pioneered this genre and sponsored the first two travelogues in Japan, In Japan (1911) and The Ainus of Japan (1913), shot by Frederick Starr. Of course, the concept of virtual tourism was not invented with the film actuality. For example, the way Japanese Wajin and Ainu are represented in these travelogues reproduced already existing patterns of representation that had been developed decades before in photography. Film in the early twentieth century was a "new medium" that adopted existing practices of "documentary" exhibition. In the nineteenth century books and illustrated journals showed readers engravings of places they could not visit, often based on daguerreotypes or other photographic processes (Lerebours 1842). John L. Stoddard and Burton Holmes, stars of the illustrated lecture circuit, travelled extensively and used photographs and then moving pictures for their sophisticated audiovisual performances (Lastra 2000, p. 100). Both had major presentations on Japan, and commissioned staged photographs of "typical" scenes, as well as made original images to convince their audiences that magic lantern presentations were "a better way to see the world than travel itself" (Barber 1993, p. 77).

In the 1920s, despite the ambiguous boundary between fiction and nonfiction, there was a growing belief in the ability of cinema to portray current events. The genre of newsreels was transformed into a new medium that would complement print journalism, although they were still released irregularly (Nornes 2003b, p. 15). As an example, the Japanese Ministry of Education commissioned The Great Kantō Earthquake (Kantō daishinsai, 1923), a documentary filmed by Shirai Sigueru, which marked the start of government involvement in film production. Commercial companies also produced earthquake documentaries to satisfy public fascination with the disaster, and the drama film studios made earthquake melodramas as soon as they were able. Although those films were dismissed as unserious in some quarters, they drew more attention to realism in the fiction film. The Nikkatsu studio in particular, though it could not reproduce the production values of Hollywood films about similar disasters, used location shooting and paratextual discourses on the traumatic experiences of the stars on the screen to create powerful forms of identification and rememoration in the audience (Lewis 2019, pp. 53-81). That potential for fictional narratives to engage the experience of real events and places is explored in several articles in this issue.

Even as the state became increasingly involved in documentary film production, the field remained widely populated by progressive or left-wing filmmakers who sympathised with Marxism, proletarian culture movements, and the class struggle that arose in the 1920s. As a response, the Japanese government sought to eliminate political dissidence and in 1925 enacted the "Peace Preservation Law" (also known as the Public Security Preservation Law), specifically designed to control the Left. In the following years, many artistic, intellectual, and culture leaders were arrested, interrogated, and imprisoned. However, activism continued in the documentary scene until at least the mid-1930s. Prokino (Nippon Puroretaria Eiga Dōmei or "Japan Proletarian Film League"), an organ of the Japanese Communist Party founded in 1929, produced documentary films and Puroretaria nyūsu (Proletarian News), as well as propaganda films, fiction films, and animated films, until its dissolution due to police persecution in 1934 (Nornes 2003b, p. 37). Even as activists performed ideological apostasy (tenk $\bar{o})$ in order to continue working, ideas about film's special ability to register the materiality of things and everyday life still circulated through such groups as the Materialism Study Society (Yuibutsuron Kenkyu Kai) (Nornes 2003b, pp. 121-47). Those ideas also motivated a shift toward realism in the feature film that was formative for the postwar generation of realist filmmakers, such as Shindō Kaneto, then working as assistants in the studios.

Despite the rise of militarism in Japan and the subsequent attacks on freedom of the press, the 1930s can be defined as a "Golden Age" of documentary. The state promoted the production of educational films (kyōiku eiga), while the fifteen-year conflict in Asia (1931-1945) was characterized by 
an unprecedented prominence of nonfiction, fuelled by the new needs of representation and social mobilization (Salomon 2011, pp. 77-78, 116-18). Film theory and feature film production also saw an efflorescence of realist theories in this period (Yamamoto 2020). This rise of documentary modes in cinema resulted in a variety of terms that began to circulate in the discussions of the time: jissha eiga (cinema of real events), kiroku eiga (documentary cinema), nyūsu eiga (news cinema), and dokyumentari eiga, borrowed from English. Also, the expression bunka eiga (culture film) was coined in 1933 as a translation of the German kulturfilm, the mainly scientific cinema produced by UFA. The term ended up designating all kinds of wartime documentary production, particularly once it was adopted in the 1939 Film Law (Eigahō).

The development of newsreels (nyūsu eiga) gave extraordinary prominence to nonfiction in the 1930s. Between 1934 and 1936, the Japanese press established the first five regular newsreels: Asashi Sekai News, Daimai Tōnichi News (by Mainichi newspaper), Yomiuri News, Dōmei News (by the eponymous news agency), and Tōhō Hassei (by the Tōhō film studio) (Imamura and Tadao 1986, p. 45). Simultaneously, "newsreel theatres", which also showed short cartoons and documentaries, emerged in the cities (Hori 2017, p. 125). The new genre experienced an extraordinary boom after the outbreak of the war with China in 1937 (Hamasaki 1999, pp. 34-35). As the number of households with relatives at the front grew, so did the number of citizens who attended cinemas to be informed about the war (Nornes 2003b, p. 50; Shimizu 1991, pp. 2-3). After the enactment of the Film Law, Japanese newsreel companies were unified under the company Nippon Eigasha (or Nichiei), following the model of Nazi Germany. The full monopolisation of Japanese newsreels was realised once Nichiei absorbed the Tōhō and Shōchiku "culture film" departments and created Nippon News.

Once Japan went to war against the Allies after the bombing of Pearl Harbour, the need for propaganda increased even further. Nichiei's budget was enlarged from two to seven million yen between 1941 and 1942. Additionally, as the Japanese Empire expanded over the Philippines, Malaysia, Thailand, French Indochina, Burma, and Chinese regions, Nichiei created branches with local versions of Nippon News, which worked as a key medium for nationalist propaganda and to promote the Pan-Asian ideal of "The Greater East Asian Co-prosperity Sphere” (Dai Tōa Kyōeiken).

\section{Wartime Tensions and the Demand for Nonfiction}

The Film Law also fuelled demand for nonfiction, since it required theatres to screen at least $250 \mathrm{~m}$ of "culture films" in each programme. As a result, documentary film production increased from 985 in 1939 to 4460 in 1940 (Nornes 2003b, p. 63). The films were deeply ideological, presenting a view of Japanese total mobilization that was pre-scripted by the state. Official narratives of famous events, such as the attack on Pearl Harbour, were presented in newspapers, contextualized by documentaries, and fictionalized in blockbuster propaganda films. In all cases, their adherence to the official narrative was supported by the documentary mode of film and photography, in which the presence of apparently realistic military hardware and uniforms reinforced the ideological claims of the figures on the screen.

However, not all nonfiction films of the 1930s followed militaristic policies. As noted above, the documentary film circles had been a stronghold for the Japanese left and ironically, much of the wartime propaganda film was made by filmmakers opposed to nationalism (Hori 2017, pp. 114-53). The most notorious example was the case of Kamei Fumio, a documentary maker linked to the Japanese Communist Party and a former member of Prokino, who proposed a kind of antimilitarist approach in his trilogy on the conflict in China: Shanghai (1937), Nanking (1937), and Peking (1938). Kamei was accused of promoting Marxism and antiwar consciousness in his films and was incarcerated in 1941 (Nornes 2003b, p. 177; Nornes 2006, p. 26). His supposed propaganda documentary Fighting Soldiers (Tatakau Heitai, 1939), which follows Japanese troops through the trenches in China, was banned.

Kamei was an isolated example, the only filmmaker to be arrested during the war. Other filmmakers resolved the tensions between national policy (kokusaku) and their political and aesthetic subjectivity in complex ways. What, from one perspective, seems like a humanist interest in the texture of everyday life or a modernist fascination with new forms of mobility or new modes of perception, 
could also be a deeply ideological discourse on national culture and the relation of individual to the collective. As Fujii Jinshi argues in this issue, the ethnographic turn toward ordinary people, first in feature films and then in bunka eiga, helped create/imagine a unified sense of the national character of the Japanese people through their representation of nonmetropolitan life. Other filmmakers emphasized the new modes of perception enabled by airplanes and optical weapons, or enlisted the perceptual apparatus of cinema to engage audiences more intensely in the war effort. Those "filmlike films" (eiga teki eiga) had more in common with ambitious feature films than what Mark Nornes called the orthodox "hard style" of more typical documentaries. Ironically, those formally ambitious films were often the most successful with audiences, and were made by liberal filmmakers who went on to support progressive post-war documentary movements, as well as movements to democratise post-war intellectual life, such as the Shiso no kagaku (Science of Thought) group (Tsurumi 1969, pp. 233-53).

It is also important to highlight women's roles in Japanese documentary film during this period. War circumstances and the increasing demand for propaganda films provided women with an opportunity to become directors, since women were replacing men in many sectors, including the film industry. Sakane Tazuko, who worked as an editor and assistant director for Kenji Mizoguchi, became the first female director in Japan with New Clothing (Hatsu Sugata, 1936). In 1940, Sakane started working for the Riken documentary company where she directed Fellow Citizens in North (Kita no doho, 1941). In 1942, Sakane moved to Manchuria to work for Man'ei (Manchurian Film Association), one of the largest film studios in Asia at the time (Yomota 2019, pp. 91-92), where she directed fourteen nonfiction films until 1945. Atsugi Taka also became a key figure for in documentary scene in wartime Japan. Atsugi had a stronger political commitment than Sakane: she had been a member of Prokino until its dissolution, and questioned the dominant ideology during and after the war. In 1934, she became the only woman employed at P.C.L. (Photo Chemical Laboratory, later part of Tōhō Studios), where she began her writing career. In 1939, her husband Mori Kōichi was arrested for his left-wing activism and Atsugi joined the documentary producer Geijutsu Eigasha (GES), where she worked as the scriptwriter for Record of a Nursery (Aru hobo no kiroku, 1942). Atsugi incorporated her opposition to nationalist education into the script, taking the approach of showing how mothers and teachers teach children a commitment to life rather than death (Ikegawa and Ward 2005, p. 266). From 1941, the mobilization of women became mandatory and the Japanese media multiplied their representations of female labour. As a consequence, Atsugi worked on various documentaries that positively portrayed the effort of women during the war, such as This Is How Hard We Are Working (Watashitachi wa konnani hataraiteiru Mizugi Sōya, 1945), in which she showed young female workers in a factory making military uniforms. Atsugi's contributions to the documentary field also include her translation in 1938 of Paul Rotha's book Documentary Film. She translated documentary film as "culture film" (bunka eiga), which sparked extensive discussion among Japanese directors.

\section{Postwar New Approaches}

\subsection{Revival of Japanese Documentary Film}

Although gendaigeki (modern day films), such as Gosho's Where Chimneys are Seen and Ozu's Tokyo Story, won prizes in Berlin and London, the postwar Japanese films that drew attention at international film festivals were mostly jidaigeki (period dramas). Filmmakers such as Kurosawa Akira, Mizoguchi Kenji, Kinugasa Teinosuke, Imai Tadashi, and Inagaki Hiroshi astonished western audiences with exotic images of a legendary Japan, receiving Academy Awards in the US as well as prizes at the Cannes, Venice, and Berlin film festivals during the 1950s. This imbalance was recognized by both contemporary and more recent writers (Giuglaris and Giuglaris 1957; Yamamoto 1983; Bordwell 1994; Centeno-Martín 2018a). However, while the Japanese production of fiction films reached its peak in this decade-1958 marked a record with 547 entertainment films (VV.AA 1963, p. 63)—the number of documentary films was even greater, reaching 1794 productions in the same year (Uni Japan 1961, p. 2). This figure clearly indicates that the production of nonfiction did not vanish with the propaganda 
films after the Japanese surrender. In fact, Japanese documentary films were not unknown in the West. In addition to tourist films (This is Tokyo), adventure films (Karakoram) and painstaking science films (Mikuro no Sekai) won prizes at western film festivals (Kusakabe 1980, back matter pp. 7-9).

In the aftermath of World War II, the documentary film industry underwent a profound restructuring. While the obligation to screen culture films disappeared with the abolition of the 1939 Film Law and theatres were reluctant to expand their programmes by including short documentaries (Yoshihara 2011, pp. 79-97), the industry experienced a revival thanks to two types of productions: "educational films" (kyōiku eiga or kyōzai eiga) and "PR films" (PR eiga). The initial impetus for the revival of the industry was the importation of American short documentaries by the Civil Information and Education (CIE) division of the Allied Occupation. The films needed to be localized by (light) reediting and the recording of a Japanese voice over. That work was carried out by existing documentary companies and branches of the feature film studios, and soon led to commissions for Japanese-made "CIE films" to be shown on donated Natco projectors at nontheatrical sites around Japan (Nakamura 2012). Although urban populations were well-supplied with commercial cinemas, the CIE films were the main form of entertainment (as well as propaganda) for rural and child audiences throughout Japan (Wada-Marciano 2019, p. 98). The interest in these films continued in the mid-1950s, as the Japanese ministries, mainly the Ministry of Education, were keen to show how the educational system had changed since the years of militarism.

In this context, Iwanami Eiga emerged as a pivotal company for the production of postwar documentary films, leaving a catalogue of around 4000 titles. Iwanami's documentary modes mainly developed around PR films, educational films, and science films, although the company also produced TV programmes and feature films. Iwanami also became a sort of documentary school where many leading figures of Japanese documentary started their careers—for example, Hani Susumu, Ogawa Shinsuke, Tsuchimoto Noriaki, and Kuroki Kazuo. Alongside these authors, two female filmmakers, Haneda Sumiko and Tokieda Toshie, made significant educational films in which they added a renewed gender perspective. Both were promoted as directors at Iwanami at the end of 1950s, during a period in which the Ministry of Education was sponsoring educational films about women.

The development of documentary film was closely linked to Japanese economic growth, and towards late-1950s this materialised in the proliferation of the PR films, which mostly were commissioned by the strategic industries of reconstruction: the steel, automobile, naval, or electrical sectors. A significant example was the Sakuma Dam series (Sakuma Damu, 1954-1957), funded by the company Dengen Kaihatsu on the construction of the first major hydroelectric dam in postwar Japan. In the process of adaptation to the postwar circumstances, these films provided the documentary producers with some financial stability (Tsuchimoto 1988, pp. 248-69; Hani 2012, pp. 30-31). However, these productions caused a great deal of frustration among documentary makers. Their promotion of capitalist power contradicted the Marxist idea of educating the masses, which was widely shared among postwar documentary circles (Irie 2006, p. 248; Hani 2012, p. 31). Where other artist groups could intervene in education or the regional avant-garde, using reportage and social realism as a means of social "engagement" (Jesty 2018), documentary filmmakers at companies such as Iwanami Productions, Nihon Eigasha, and Shin Riken Eiga Kaisha worked in the service of the high-growth capitalist economy. This contradiction prompted artistic and ethical debates among documentary makers from the early sixties, such as those published in Kiroku eiga (Yamane 1993). Authors such as (Mamiya 1962) rejected the notion that PR films could be a laudable task for documentary makers. Similarly, the veteran Yoshino Keiji showed a feeling of defeat toward the end of their career and questioned whether these films had been useful for society (cited by Hani 1985, p. 138). While sharing the same concern, others like Kuroki Kazuo claimed that the PR film might be used for artistic experiment with cinematic language (cited in Yamane 1993). Hani also noted that the technical and artistic quality of many PR films had been overlooked (Hani 1985). More recently, authors have highlighted the films' historical value as exceptional witnesses to an era (Hani 2012, pp. 83-165; Toba 2010). 
While cinema had become the main medium to foster documentary modes of representation in the previous decades, this role started to be taken over by television from the 1950s. Since the first NHK broadcast in 1953, the number of television broadcasts increased rapidly, reaching 10 million by 1960 (Toda 2006, p. 155). The big studios tried to keep their hegemony in the entertainment sector and did not allow films to be broadcast on television, and as a consequence, much of the programming was filled by American films during the first years (De Castillon 1975, p. 17). However, television companies reached agreements with the film studios from 1955, and from that time the development of documentary modes in cinema and television became intertwined. News and reportage programmes were shot on film, and both documentary and feature filmmakers transferred from cinema to television. Thus, television stations became a meeting point for directors, as well as scriptwriters and professionals with different backgrounds (newsreels, journalism, art, and entertainment film). Also, many companies, including those outside the big studios such as Iwanami, engaged in the production of documentaries for television, for which Masaaki Segawa coined the term terementarī, a combination of the Japanese words for television and documentary. ${ }^{2}$ Hani applied this concept to all information and social programmes made for television, and noted that terementari was not merely an exhibition format but also entailed a new style that demanded a renewed personal approach to reality (Hani 1960, pp. 69-76).

As the number of nonfiction genres produced for television increased, so did the discussions on the possibilities of the television documentary proliferated from the end of the decade. Many of them were led by the first generation of filmmakers, who worked for television such as Hani Susumu, Ushiyama Yunichi, Okamoto Yoshihiko, and Yoshida Naoya (see Hani et al. 1959). Authors in general believed that television would allow a closer engagement with reality and had high expectations in the degree of truthfulness it might bring. Hani, for example, highlighted the realism found in fiction series such as Watashi wa kai ni naritai (Okamoto Yoshihiko, KRT 1958), in which characters acted with great naturalness and seemed to play themselves (Hani 1959, p. 199).

\subsection{New Critical Approaches}

Japan has a long history of image and film theory. Filmmakers, as well as theorists and critics, engaged in prolific debates about documentary practice and the nature of images from the 1930s to the 1970s. While these discussions have been neglected in English language scholarship for decades, recent work has discussed, for example, the conflict between Iwasaki Akira and Imamura Taihei about realism in documentary film and its ideological implications (Irie 2010, pp. 71-75). In Japan, Atsugi Taka's translation of Paul Rotha's Documentary Film also triggered intense debate, which involved a wide range of intellectuals such as Hasegawa Nyōzekan, Tosaka Jun, Kamei Katsuchirō, and Nakai Masakazu (Nornes 1999). Other debates, such as the ethical concerns about the filmmaker's social responsibility, developed by Iijima Tadashi, Tsumura Hideo, and Futaba Jūzaburō, still wait for scholarly scrutiny. Many of those critics, such as Imamura Taihei, recognized the documentary aspect of both fiction and nonfiction film. The self-reflexive criticism developed by postwar filmmakers has also been recognized in recent years (Furuhata 2007, 2013; Raine 2012; Centeno-Martín 2018b, 2020a). Articles in this special issue continue that exploration, both in wartime (Fujii, Miyao) and postwar periods (Kitsnik, Centeno-Martín, Jesty, Mihalopoulos, Inoue, Coates).

The enormous growth of documentary as a field after World War II produced an astonishing intellectual ferment around politics, aesthetics, and genre. The hidebound feature film studios were strongly hierarchical and run by anticommunist leaders, so many ex-student radicals ended up working in documentary alongside leftists who were pushed out of the Toho studio after a series of postwar strikes. That political engagement, opposed to previous wartime propaganda, initiated critical discussions of current affairs and engaged in topics that had been taboo during the war. The Japanese

2 The text by Segawa Masaki. 1959. Dokyumentari no hōkō (Documenatry Direction). Kinema Junpō 8 is cited in (Hani 1960, p. 69). 
Tragedy (Nihon no Higeki, 1946) is an early example, in which Kamei Fumio accused Japanese leaders, including the emperor, of war crimes. Kamei went on to make antinuclear films and a series of documentaries that mobilised support against the expansion of the US air base at Tachikawa in the 1950s (Raine 2019). Later, in the context of the protests against the US-Japan Security Treaty, a younger generation of documentary makers, such as Ogawa Shinsuke, Tsuchimoto Noriaki, and Adachi Masao, epitomised the Japanese militant cinema from the 1960s. Those filmmakers were often at odds with the established cultural policies of the Japanese Communist Party (JCP), creating a split that was symptomatic of the rise of the "New Left" in Japan.

That political division was in part driven by aesthetic differences. Where the established left had a strong concept of the "party line", new filmmakers wished to liberate directors from social, political, and authoritarian constraints and explore individual freedom in capturing reality. They shared that interest in authorship and subjectivity with the proliferating culture circles, formed in the aftermath of World War II, in which writers, journalists, painters, critics, filmmakers, and other artists proposed alternative modes of authenticity to the reportage and social realism established on the Left (Matsumoto 2012). These alliances between avant-garde circles and documentary films have recently become an object of inquiry (Matsumoto and Kenji 2008; Toba 2010; Raine 2012; Furuhata 2013; Key 2011; Centeno-Martín 2019), which is expanded further in this special issue by Toba. Filmmakers such as Matsumoto Toshio, Teshigahara Hiroshi, Kuroki Kazuo, and Hani Susumu engaged in a quest for new methods to explore reality. Some decades later, that New Left social orientation was challenged in turn by radical notions of subjectivity that underpinned intimate documentaries about filmmakers' private lives, including close depiction of partners and other family members. Documentary filmmakers such as Kazuo Hara in the 1970s, Kawase Naomi in the 1990s, and Yang Yong-hi in the 2000s have dismantled the traditional distinction between filmed subject (shutai) and filmed object (taishō), making it necessary to update previous debates about the filmmaker's role in the profilmic world.

Strikingly, much of the hardest thinking about the documentary aspect of cinema took place in out-of-the-way areas of the Japanese film industry, such as the producers of educational and PR films. Matsumoto Toshio, who would become an important avant-garde filmmaker and theorist, had attended the study group for the Documentary and Educational Film Producers Conference (Kiroku Kyōiku Eiga Seisaku Kyōgikai, known as Seikyō), led by prewar leftist filmmakers Noda Shinkichi and Atsugi Taka. The group went on to publish Kiroku eiga, a journal that, after Matsumoto and his allies took over editorial control in 1960, attracted contributions from theorists of art, literature, and fiction as well as nonfiction filmmaking (Raine 2012). In this "age of the document" (kiroku no jidai, Toba 2010), critical explorations of the documentary mode also questioned the boundary between fiction and nonfiction formats. Filmmakers, both inside and outside the major film studios, strove for a "cinema of actuality" (Furuhata 2013) that broke through the artificial wall of conventional "storyism" (Yoshida 1960). Many other groups, such as the Documentary Art Group (Kiroku Geijutsu no Kai), produced journals such as Gendai geijutsu that continued those debates. Matsumoto was also a marginal member of the Blue Group, a study group centred on young filmmakers at Iwanami to discuss both their current work and the projects they could not realize at the company (Nornes 2007, pp. 16-19). That group formed the nucleus of a series of documentary filmmakers, especially directors and cinematographers such as Hani Susumu and Tamura Masaki, who went on to work in both fiction and nonfiction genres during the 1960s and 1970s.

\section{Goals and Structure of This Special Issue}

The documentary mode is an essential part of Japanese film culture, whose role in film history has been recognized only recently. Some authors have provided a general historical overview of the documentary film (Satō 2010; Kurosawa et al. 2010), while others have focused on certain aspects: short documentaries (Yoshihara 2011; Harada 2012; Fujii 2002), Iwanami Eiga productions (Kusakabe 1980; Hani 2012; Tsunoda 2015), the variety of nonfiction genres (Takeda 2017), prewar and wartime non-fiction (Okudaira 1986; Kurasawa 1987; Fujii 2001; Hori 2002; Nornes 2003b; Centeno-Martín 2017; 
Morita 2018) and postwar movements (Nornes 2003a; Centeno-Martín 2020b). In recent years, there has been a growing interest in treating certain documentary makers as auteurs, such as Sakane Tazuko (Ikegawa 2011; McDonald 2007), Tsuchimoto Noriaki (Jesty 2011; Bingham 2009; Gerow and Noriaki 2014; Inoue 2018), Ogawa Shinsuke (Nornes 2007); Hani Susumu (Briciu 2013; Centeno-Martín 2015), Matsumoto Toshio (Matsumoto and Kenji 2008; Raine 2012), and Hara Kazuo (Ruoff and Ruoff 1993).

Although there are older histories of documentary film that survey early actualities, bunka eiga, educational films, PR films, socially committed documentaries, television documentaries, and so on (Satō 1977), and more focused volumes on single production companies (Kusakabe 1980), few works have recognized Nichols' stipulation that documentary is a "fiction (un)like any other". Documentary is not just a genre but a mode (or modes); filmmakers in Japan have long explored the special power of cinema to compel a sense of authenticity, even when put in service of fictional worlds. From 1920s earthquake documentaries to the 1930s films influenced by contemporary debates over materialism, and from the ideological hypostatisation of a unitary Japanese nation in wartime culture films to 1960s radical documentaries that unashamedly "stood on the side of the subject" (Nornes 2007, p. 30), the putative boundary between documentary and dramatic films was frequently crossed in Japanese cinema. If terms such as "documentary touch" and "semi-documentary" were mere journalistic shorthand in post-war film criticism, Coates, Kitsnik, and Mihalopoulos make clear in this volume that some filmmakers made more stringent efforts to develop fictional worlds using at least some of the rhetorical forms and ethical commitments that underpin documentary's "impression of authenticity". In that context, it is vital that current studies develop more comprehensive approaches by interrogating the alliances and dialogues between documentary and other media and artistic practices, to avoid compartmentalising documentary films away from the rest of film history. Developments in Japanese Documentary Mode proposes new approaches to the history and theory of nonfiction genres and adjacent formats that contribute to identifying, analysing, and categorising distinctive uses of the documentary mode in Japan.

In his article, Fujii Jinshi identified an "inversion", through which, despite their shared goal of representing the ignored margins of Japan, the historical coincidence and methodological compatibility of the wartime documentary (bunka eiga) and Japanese ethnography (minzokugaku) supported the Japanese State in its ideological construction of a unitary and homogenous "Japanese Nation". Motivated by a "discourse of the vanishing", which described traditional Japanese culture as retreating in the face of forced modernization, both bunka eiga and minzokugaku drew on a contemporary intertextual field of ethnographic photography and reportage to attempt to document the disappearing lifeways of Japan. However, reviewing the "cameraman-viewfinder debate" between Miki Shigeru and Kamei Fumio, Fujii showed that cameraman-director Miki's collaboration with famous ethnographer Yanagita Kunio, recapitulated the tension in all documentary practices between a respect for the real and a desire to control it. Miki and Yanagita's documentary and spinoff photographic album covered over the heterogeneity of Japan, with representative images that came to stand for what could not be seen. Rather than a true representation of reality, their work served as an escape from it.

Miyao Daisuke also drew on the "cameraman-viewfinder debate" to highlight the tension between two longstanding discourses on documentary filmmaking: the film image as a mechanical reproduction of reality and documentary cinema as the creative treatment of actuality. He argued that wartime commentators played down the creative aspects of documentary in favour of the immediacy of the newsreel, a kind of zero degree recording that was even praised in feature films as an example of "documentary spirit" (jissha seishin). Through a discourse analysis of articles mostly in the influential trade journal Eiga gijutsu, he showed how that tension was resolved for makers of bunka eiga (culture films) by a strategic use of the world "culture". Culture was used not in Raymond Williams' modern sense of ordinary life (Williams 1958), but in the sense of education and refinement: cultured documentary filmmakers were both au fait with the modern science and technology of optics and imported cameras that produced their apparently automatic images and at the same time knowledgeable about the Japanese culture that they were newly commissioned to support. Concluding 
in a similar vein to Fujii, Miyao showed how that cultural knowledge was implicitly in opposition to Americanised popular culture, and complicit with the cultural nationalism of wartime Japan.

Toba Koji cast light on the documentary scene in Japan since the 1950s. This article provides keys to understand certain aspects of the media production of the time by exploring the interactions between magic lantern and documentary films. Toba proposed an innovative analysis of the relationship between Japanese documentary film and the cultural context of the time, including changes in postwar education, political activism, and the postwar "democracy" spirit in cultural productions and collaborative works. Toba demonstrated how the documentaries expanded beyond cinema and should be studied in relation to what is not in the film, becoming a sort of macrotext, which is comprised of a various media and artistic works that complement each other (mainly magic lantern productions, but also poetry, illustrated books, and so on). This approach also entails paying attention to the filmmaker's alliances with social actors, without which the films cannot be completely understood, ranging from artists, such as sculptors and painters, as well as local communities (students, teachers) and local historians.

The following three articles (Centeno-Martín, Jesty, and Inoue) explored the documentary scene from 1950s Japan and analysed tendencies that were articulated through shared innovative approaches to filmmaking. Centeno-Martín took Hani's film theory and practice as a starting point to demonstrate how this author pioneered a filmmaking method based on an extraordinary engagement with the filmed environment and created a sort of "documentary school". Centeno-Martín explained how Hani's theoretical framework was aimed at exploring inner worlds existing in the external world by following his principle of filming "protagonists who do not act". The article illustrates how Hani applied his methodology to a film without living characters, which focused instead on the architecture of Hōryūji temple. This example became one of the boldest attempts of the time to explore subjectivities and inner universes in the filmed objects and shows how the avant-garde documentary movement evolved in a variety of unexpected directions in late 1950s. The analysis is contextualised within the intellectual and artistic scene, including (trans)national influences as well as the ideological and aesthetic rupture among Japanese New Left artists. Centeno-Martín traced how Hani's method was expanded to Teshighara and Adachi's avant-garde documentaries, interrogating subjective dimensions in rural, urban, and architectural landscapes.

The relationship among these directors, largely unexplored to date, is essential to a comprehensive view of the documentary scene in post-war Japan. Assessing these artistic links and common practices, rather than studying films as isolated works, is instrumental to identifying collective tendencies of the time. Jesty explored this issue further by analysing how Hani's theories and films from the 1950s were expanded by Tsuchimoto in the early 1970s. The article provides a sharp and in-depth understanding of Hani's methodological framework, the nature of his collective works founded on the rejection of scripts, actors, and staged shooting, as well as its reliance on long-running involvement with the subjects in the film. Jesty engaged in important epistemological keys, such as Hani's singular notion of performance (engi), which is only true to life when shots capture changes in individuals as a consequence of being exposed to unfamiliar environments. Jesty explained how, to a certain extent, Tsuchimoto expanded Hani's approach in his lifelong engagement with Minamata victims. The article also demonstrates that despite apparent similarities with cinéma vérité in the US and France, Japanese authors developed an original pragmatic method seeking to reveal the dynamics of the subject's "life-world", which was not conceived to exist apart from the filmmakers. Films require partial mediation that should be carried out through receptivity and long observation. Thus, Jesty defined this film practice shared by Hani and Tsuchimoto as an "intersubjective" process, since the moving image's ability to project the subject's life-world emerges from the interdependence of the people involved in the film, both filmmakers and filmed subjects.

Inoue expanded Jesty's analysis by engaging in a discussion of the ethical dimension of Tsuchimoto's documentary practice. The article shows how Tsuchimoto's close gaze on the human being, which is based on interactions between individuals, becomes problematic when representing filmed 
subjects (shutai) who remain unconscious or unable to express themselves, like victims of Minamata disease. How can filmmakers deal with subjects who can't interact? Is it ethically right to film them in the first place? Inoue engaged in this ethical debate that has relevant implications for contemporary media practices. By comparing Tsuchimoto's films with Eugene Smith's photography, Inoue showed how the threshold between an abusive usage of a subject's life and an ethical representation is extremely subtle but equally meaningful. Tsuchimoto's concerns about the potential danger that the camera may trigger on filmed subjects is precisely what makes his approach valuable.

Kitsnik analysed Shindō Kaneto's interest in working with real events and using a variety of documentary film resources, tropes, and patterns of representation as part of the filmmaker's engagement with postwar cinematic experiments on the boundaries between reality and fiction. The article raises crucial questions through the close observation of Shindō's oeuvre: questions of ethics and the impossibility of making "nonfiction" films given the unavoidable existence of an author and the subsequent cinematic artifice that makes any attempt to capture reality objectively unattainable. Thus, Kitsnik illustrated how Shindō's work is a mixture of documentary and fiction formats, articulated in a hybrid and stylised manner. This study is also useful to understand the context in which other avant-garde filmmakers of the time, such as Oshima and Matsumoto, engaged in this film experienced challenging the boundaries between fiction and nonfiction by combining historic events, media footage, and interviews with re-enactments or fictional stories.

Turning to Imamura Shohei, a filmmaker whose career spans both feature films and documentaries, Bill Mihalopoulos argued that many of Imamura's films are characterized by a promiscuous fusion of the "immediacy and authenticity associated with documentary film-making" and the "character development and dramatic arc" typical of the fiction film. When Imamura turned to documentary filmmaking in the 1960s, the films were similarly experimental and reflexive. Focusing on Imamura's 1970 documentary History of Post-war Japan as Told by a Bar Hostess, Mihalopoulos argued that the juxtaposition of interview and newsreel documentary modes, layered in the same shot, disrupted the dominant narrative of post-war Japan. The interval between the two modes allows us to perceive, simultaneously and ambivalently, the interview subject's shameless vitality as well as her self-commodification and indifference to her complicity in the public events shown behind her. Unlike the wartime films discussed by Fujii and Miyao, the dialectic of public and private in the film foregrounds the heterogeneity of life as it is in Japan. Mihalopoulos concluded that in place of the orthodox story of democratization and economic growth, Imamura's film suggests a "radical change in personality", in which Japanese respond to intensified postwar capitalism with "greed, violence, and cold indifference".

Jennifer Coates also cast a wide net over the history of documenting practices in the cinema. Starting with the earliest actualities, Coates questioned national and genre divisions in film analysis. Drawing on the concept of ethnofiction from visual anthropology, Coates extended its definition from subjects improvising their own lives on camera to argue that scripted prewar documentaries were a form of ethnofiction, as were wartime films that, like ethnofiction, dramatized real events. This historical revisionism enabled a critique of origins: ethnofiction is usually traced to French cinema verité, but Coates argued that it was a common-sense approach in Japan from the 1950s to the present day, from Japanese filmmakers such as Imamura Shohei to filmmakers working in Japan, such as Hou Hsiao Hsien. Ethnofictional practices in those films included research into real people's lives and a provocative or reflexive relation between filmmaker and subject/character. Coates went on to argue that recognizing Japanese feature films as ethnofictions allows us to recognize that blend of fictional and documentary techniques as a polycentric global innovation with geographic and temporal specificities.

We would like to thank these authors for responding to our initial call for papers, and for their careful revisions of their essays. We are pleased to present their work in public and hope the various arguments and histories documented here will spark further research and discussion among our readers.

Conflicts of Interest: The authors declare no conflict of interest. 


\section{References}

Anderson, Joseph, and Richie Donald. 1982. The Japanese Film: Art and Industry. Princeton: Princeton University Press, (originally published in Tokyo, Rutland VT.: C.E. Tuttle Co, 1959).

Barber, X. Theodore. 1993. The Roots of Travel Cinema: John L. Stoddard, E. Burton Holmes, and the Nineteenth-Century Illustrated Travel Lecture. Film History 5: 68-84.

Bingham, Adam. 2009. Filmmaking as a way of life: Tsuchimoto, Ogawa, and revolutions in documentary cinema. Asian Cinema 20: 166-75. [CrossRef]

Bordwell, David. 1994. Film History: An Introduction. New York: McGraw Hill.

Briciu, Bianca. 2013. Love and power: The objectification of the adolescent body in Hani Susumu's Hatsukoi jigokuhen/Nanami, inferno of first love (1968). Journal of Japanese and Korean Cinema 5: 59-76. [CrossRef]

Brooks, Peter. 1976. The Melodramatic Imagination: Balzac, Henry James, Melodrama and the Mode of Excess. New Haven: Yale University Press.

Centeno-Martín, Marcos P. 2015. Susumu Hani (1950-1960): The Theoretical and Practical Contribution to the Japanese Documentary and Youth Cinema. An Approach to Hani's Case as a Precursor of the New Wave. Ph.D. dissertation, University of Valencia, Valencia, Spain.

Centeno-Martín, Marcos P. 2017. Transnational Circulation of Images of the Pacific War (1941-1945): The Japanese Empire Seen through Spanish Newsreels. Irish Journal of Asian Studies (IJAS) 3: 1-13.

Centeno-Martín, Marcos P. 2018a. Introduction. The Misleading Discovery of Japanese National Cinema. Arts 7: 87. [CrossRef]

Centeno-Martín, Marcos P. 2018b. The Limits of Fiction: Politics and Absent Scenes in Susumu Hani's Bad Boys (Furyō Shōnen, 1960). A Film Re-reading through its Script. Journal of Japanese and Korean Cinema 10: 1-15. [CrossRef]

Centeno-Martín, Marcos P. 2019. Postwar Narratives through Avant-garde Documentary: Tokyo 1958 and Furyō Shōnen. In Persistently Postwar. Media and the Politics of Memory in Japan. Edited by Artur Lozano, Dolores Martínez and Blai Guarné. New York and Oxford: Berghahn Books, pp. 41-62.

Centeno-Martín, Marcos P. 2020a. From Japan to Africa: Transnationality in Hani Susumu's Theory and Cinematic Experience from Japan to Africa". In Japan beyond Its Borders: Transnational Approaches to Film and Media. Edited by Marcos P. Centeno-Martín and Morita Nori. Tokyo: Seibunsha, pp. 113-26.

Centeno-Martín, Marcos P. 2020b. Crónicas de Paisaje. Nuevas formas de subjetividad en la vanguardia documental japonesa. In Memoria y paisaje en el cine japonés de posguerra. Edited by Pedro Iacobelli and Claudia Lira. Santiago de Chile: Ediciones Universidad Católica de Chile, pp. 287-335.

De Castillon, Pierre. 1975. Notes et Etudes Documentareis. Le Cinéma Japonais 8: 16.

Fujii, Jinshi. 2001. Torarenakatta shotto to sono unmei: Jihen to eiga 1937-1941 (Shots that could not be taken and their fate: The China Incident and cinema, 1937-1941). Eizōgaku (Visual Studies) 67: 23-40.

Fujii, Jinshi. 2002. Films That Do Culture: A Discursive Analysis of Bunka Eiga, 1935-1945. Iconics 6: 51-68.

Furuhata, Yuriko. 2007. Returning to Actuality: Fūkeoron and the Landscape Film. Screen 48: 345-62. [CrossRef]

Furuhata, Yuriko. 2013. Cinema of Actuality: Japanese Avant-Garde Filmmaking in the Season of Image Politics. Durham: Duke University Press.

Gerow, Aaron, and Tsuchimoto Noriaki. 2014. Tsuchimoto Noriaki. Documentarists of Japan No. 7. Documentary Box. Available online: http://www.yidff.jp/docbox/8/box8-2.html (accessed on 21 May 2020).

Giuglaris, Shinobu, and Marcel Giuglaris. 1957. Le cinema Japonais. Paris: du Cerf.

Greenberg, Larry. 2001. The Arrival of Cinema in Japan. In The Benshi. Japanese Silent Films Narrators. Edited by Matsuda Eigasha. Tokyo: Urban Connections, pp. 6-12.

Grierson, John. 1933. The Documentary Producer. Cinema Quarterly 2: 7-9.

Grierson, John. 1979. Flaherty's Poetic Moana. In The Documentary Tradition, 2nd ed. Edited by Lewis Jacobs. New York: W. W. Norton, pp. 25-27, Originally published under the byeline The Moviegoer in New York Sun, 8 February 1926.

Hamasaki, Koji. 1999. Nyūsu eiga kōkogaku: Katsudō shashin 1 Shadan hōjin Nihon Nyūsu-eiga-sha setsuritsu made: 1896-1940 (Newsreel Archaeology. 1 From action photos to the creation of Nihon Nyūsu eiga-sha: 1896-1940). Kawasaki-shi Shimin Myüjiamu kiyō 11: 34-35.

Hani, Susumu. 1959. Terebi prodyūsā e no chōzenjō. Kagami ni natteshimatta mado (Letter to Challenge Television Producers. The Window which became a Mirror). Chūo Kōron 74: 199. 
Hani, Susumu. 1960. Terementarī ron (Terementari Theory) in Gendai terebi kōza. Edited by Kakutarō Kanazawa. Tokyo: Daviddosha, pp. 69-76.

Hani, Susumu. 1985. Aru tokuina rīdā ni tsuite no kaisō. Iwanami Eiga ni okeru jinzai ikusei o sasaeta mono (Reflection on some singular leaders. Training talents at Iwanami Eiga). Rekishi to shakai 6.

Hani, Susumu. 2012. Boku to Iwanami Eiga (Iwanami Eiga and I). In Iwanami Eiga no 1-oku furēmu (Images of Postwar Japan. The Documentary Films of Iwanami Productions). Edited by Niwa Yoshiyuki and Yoshimi Sun'ya. Tokyo: Tokyo Daigaku Shuppankai, pp. 21-38.

Hani, Susumu, Ushiyama Yunichi, Okamoto Yoshihiko, and Yoshida Naoya. 1959. Warera wa terebi prodyūsā (We, Television Producers). Chūō Kōron 74: 225.

Harada, Ken'ichi. 2012. CIE Eiga/Suraido no Nihonteki Juyō: “Niigata” to iu Jirei Kara (Japanese Reception of CIE Films/Slides: From the case of "Nigata"). In Senryō suru Me, Senryō suru Koe: CIE/USIS Eiga to VOA Rajio. Edited by Yuka Tsuchiya and Yoshimi Shun'ya. Tokyo: Tokyo Daigaku Shuppankai.

Hori, Hikari. 2002. Senchū, senryōki kōteki media ni okeru joseizō no hensen (Images of Women in Newsreels of Wartime and Occupation Japan). Journal of Gender Studies Japan 4: 29-46.

Hori, Hikari. 2017. Promiscuous Media. Film and Visual Culture in Imperial Japan, 1926-1945. Ithaca: Cornell University Press.

Ikegawa, Reiko. 2011. Teikoku no eiga kantoku Sakane Tazuko. (Sakane Tazuko, Empire's Film Director). Tokyo: Yoshikawa.

Ikegawa, Reiko, and Julian Ward. 2005. Japanese Women Filmmakers in World War II: A Study of Sakane Tazuko, Suzuki Noriko and Atsugi Taka. In Japanese Women Emerging from Subservience, 1868-1945. Edited by Gordon Daniels and Hiroko Tomida. Folkestone: Global Oriental, pp. 258-77.

Imamura, Shōhei, and Satō Tadao, eds. 1986. Sensō to Nihon eiga (War and Japanese Film). Tokyo: Iwanami Shoten. Inoue, Miyo. 2018. Exhibition, Document, Bodies: The (Re)presentation of Minamata Disease. Ph.D. dissertation, University of California, Berkeley, CA, USA.

Irie, Takanori. 2006. Iwanami Eiga no ni nenkan (Two Years in Iwanami Eiga). Seiron 417: 244-53.

Irie, Yoshirō. 2010. Approaching Imamura Taihei and the Originality of His Film Theory. Review of Japanese Culture and Society 22: 60-79.

Jesty, Justin. 2011. Making mercury visible: The Minamata documentaries of Tsuchimoto Noriaki. In Mercury Pollution: A Transdisciplinary Treatment. Edited by Michael C. Newman and Sharon Zuber. Abingdon: Taylor and Francis, pp. 139-60.

Jesty, Justin. 2018. Art and Engagement in Early Postwar Japan. Ithaca: Cornell University Press.

Key, Margaret S. 2011. Truth from a Lie: Documentary, Detection, and Reflexivity in Abe Kobo's Realist Project. New York: Lexington Books.

Koga, Futoshi. 1995. 'Meiji no Nihon' kara 'Rumieru eiga Nihon-hen'e (From Meiji Japan to Lumière Films Japan Edition). In Eiga Denrai. Edited by Yoshishige Yoshida, Masao Yamaguchi and Naoyuki Kinoshita. Tokyo: Iwanami Shoten.

Komatsu, Hiroshi. 1992. Some characteristics of Japanese Cinema before World War I. In Reframing Japanese Cinema. Authorship, Genre, History. Edited by Arthur Nolleti and David Desser. Bloomington: Indiana University Press, pp. 238-44.

Kurasawa, Aiko. 1987. Japanese Film Propaganda in Java 1942-1945. Indonesia 44: 59-116. [CrossRef]

Kurosawa, Kiyoshi, Yomota Inuhiko, and Yoshimi Shunya. 2010. Nihon eiga wa ikiteiru dai 7 kan: Fumikoeru dokyumentari (Japanese Cinema is Alive Volume 7: Documentary that Overcomes). Tokyo: Iwanami Shoten, pp. 111-30.

Kusakabe, Kyūshirō. 1980. Eizō o tsukuru hito to kigyō: Iwanami Eiga no sanjūnen (Filmmakers and Companies: Thirty Years of Iwanami). Tokyo: Mizuumi Shobō.

Lastra, James. 2000. Sound Technology and the American Cinema. New York: Columbia University Press.

Lerebours, N. P. 1842. Excursions Daguérriennes: Vues et Monuments les plus Remarquables du Globe (Daguerrian Excursions: The Most Remarkable Views and Monuments in the World). Paris: Rittner et Goupil.

Lewis, Diane Wei. 2019. Powers of the Real: Cinema, Gender, and Emotion in Interwar Japan. Cambridge: Harvard University Asia Center.

Mamiya, Norio. 1962. 1962-nen no 'watashi' (The 'Me' of 1962-How To Shoot PR Films). Kiroku Eiga 11.

Matsumoto, Toshio. 2012. A Theory of Avant-Garde Documentary. Cinema Journal 51: 148-54. 
Matsumoto, Toshio, and Ishizaka Kenji. 2008. Dokyumentarii no Umi e: Kiroku Eiga Sakka Matsumoto Toshio to no Taiwa (Toward a Documentary Sea: A Conversation with Documentary Filmmaker Matsumoto Toshio). Tokyo: Gendai Shokan.

McDonald, Keiko I. 2007. Daring To Be First: The Japanese Woman Director Tazuko Sakane (1904-1971). Asian Cinema 18: 138-46. [CrossRef]

Morita, Noriko. 2018. Geijutsu eiga-sha ni yoru seisaku genba no hen'yō: Senji-ki Nihon ni okeru “dokyumentarī" no hōhō-ron no jissen. (The Transformation of the Production Site by Geijutsu Eigasha: The implementation of the "Documentary" Method in Wartime Japan). Eizogaku 100: 10-31.

Murayama, Hideo. 2010. Kiroku eiga no hozon to genjō (Contemporary Situation of Documentary Film Preservation). In Shirīzu Nihon no dokyumentarī 4. Sangyō, kagaku hen. Edited by Satō Tadao. Tokyo: Iwanami Shoten.

Musser, Charles. 1994. The Emergence of Cinema: The American Screen to 1907. Berkeley: University of California Press.

Nakamura, Hideyuki. 2012. Akatsuki ni au made: 'Iwanami Eiga' to 'me' no shakaiteki sōzō (Meeting at Sunrise: Iwanami Eiga and the Creation of a Social Gaze). In Iwanami Eiga no 1-oku furēmu (Images of Postwar Japan. The Documentary Films of Iwanami Productions). Edited by Niwa Yoshiyuki and Yoshimi Sun'ya. Tokyo: Tokyo Daigaku Shuppankai, pp. 39-58.

Nichols, Bill. 2017. Introduction to Documentary, 3rd ed. Bloomington: Indiana University Press.

Nornes, Abe Mark. 1999. Pôru Rûta/Paul Rotha and the Politics of Translation Part 1. Cinema Journal 38: 91-108.

Nornes, Markus. 2003a. The Postwar Documentary Trace: Groping in the Dark. Positions: East Asia Cultures Critique 10: 39-78. [CrossRef]

Nornes, Abé Mark. 2003b. Japanese Documentary Film: The Meiji Era through Hiroshima. Minneapolis: University of Minnesota Press.

Nornes, Abe Mark. 2006. El magisterio de Fumio Kamei. In El Cine de los Mil Años: Una Aproximación Histórica y Estética al Cine Documental Japonés (1945-2005). Edited by Carlos Muguiro. Pamplona: Colección Punto de Vista, p. 22, (The Typical Genius of Kamei Fumio, Yamagata International Documentary Film Festival, originally published in 2001.).

Nornes, Abé Mark. 2007. Forest of Pressure: Ogawa Shinsuke and the Postwar Japanese Documentary. Minneapolis: University of Minnesota Press.

Okudaira, Yasuhiro. 1986. Eiga no Kokka Tōsei. In Kōza Nihon eiga 4: Sensō to Nihon eiga. Tokyo: Iwanami Shoten.

Raine, Michael. 2012. Introduction to Matsumoto Toshio: A Theory of Avant-Garde Documentary. Cinema Journal 51: 144-47. [CrossRef]

Raine, Michael. 2019. The Cold War as Media Environment in 1960s Japanese Cinema. In The Cold War and Asian Cinemas. Edited by Poshek Fu and Man Fung Yip. London: Routledge.

Richie, Donald. 1990. Japanese Cinema. An Introduction. Hong Kong, New York and Oxford: Oxford University Press.

Ruoff, Kenneth J., and Jeffrey K. Ruoff. 1993. Filming at the Margins: The Documentaries of Hara Kazuo. Image Theory, Image Culture, and Contemporary Japan. Iris 16: 115-26.

Salomon, Harald. 2011. Views of the Dark Valley_Japanese Cinema and the Culture of Nationalism, 1937-1945. Wiesbaden: Harrassowitz Verlag.

Satō, Tadao. 1977. Nihon kiroku eizōshi (History of the Japanese Documentary Image). Tokyo: Hyōronsha.

Satō, Tadao. 2010. Shirīzu Nihon no dokyumentarī (Japanese Documentary Series). Tokyo: Iwanami Shoten.

Shimizu, Akira. 1991. Nichi-Bei eigasen (Japanese-American War Films). Tokyo: Seikyūsha.

Takeda, Tōru. 2017. Nihon nonfikushon shi: Ruporutāju kara akademikku jānarizumu made (A History of Japanese Non-Fiction: From Reportage to Academic Journalism). Tokyo: Chūō Kōron Shinsha.

Toba, Kōji. 2010. 1950 nendai: 'Kiroku' no jidai (1950s: The Documentary Age). Tokyo: Kawade Shobō Shinsha.

Toda, Keita. 2006. Iwanami Eiga Seisakujo to 60 nendai dokyumentarī eiga no shuppatsu: Tsuchimoto Noriaki sakuhin ni miru shoki terebi to no kakawari wo chūshin ni (Iwanami Eiga Productions and the beginning of 1960s Documentaries: Focusing on Noriaki Tsuchimoto and his Early Television Work). The Sociologist. Journal of the Musashi Sociological Society 8: 145-271.

Tsuchimoto, Noriaki. 1988. Shiron, Dokyumentarī eiga no 30 nen (My Theory, 30 Years of Documentary Film). In Kōza Nihon eiga 7: Nihon eiga no genzai. Tokyo: Iwanami Shoten, pp. 248-69.

Tsunoda, Takuya. 2015. The Dawn of Cinematic Modernism: Iwanami Productions and Postwar Japanese Cinema. Ph.D. dissertation, Yale University, New Haven, CT, USA. 
Tsurumi, Shunsuke, ed. 1969. Kataritsugu Sengoshi I (Passed-Down Postwar History, Part 1). Tokyo: Shisō no Kagakusha.

Uni Japan. 1961. Japanese Films 1961. Non-Dramatic Subjects. Tokyo: Uni Japan, Association for the Diffusion of Japanese Films Abroad.

VV.AA. 1963. Eiganenkan. Tokyo: Jijitsūshinsha.

Wada-Marciano, Mitsuyo. 2019. Educational Films in Postwar Japan: Traces of American Cultural Policies in the Cold War Period. In The Cold War and Asian Cinemas. Edited by Poshek Fu and Man-Fung Yip. New York and London: Routledge.

Williams, Raymond. 1958. Culture is Ordinary. In Conviction. Edited by Norman MacKenzie. London: MacGibbon and Key.

Yamamoto, Kikuo. 1983. Nihon eiga ni okeru gaikoku eiga no eikyō (The Influence of Foreign Cinema on Japanese Cinema). Tokyo: Waseda Daigaku Shuppanbu.

Yamamoto, Naoki. 2020. Dialectics without Synthesis: Japanese Film Theory and Realism in a Global Frame. Berkeley: University of California Press.

Yamane, Sadao. 1993. Changes in 1960s Documentary Cinema from PR films to Image Guerilla. In Japanese Documentaries of the 1960s. Tokyo: Yamagata Film Festival, pp. 14-20.

Yomota, Inuhiko. 2019. What is Japanese Cinema? A History. New York: Columbia University Press.

Yoshida, Kijū. 1960. Eiga no kabe: Stōrī-shugi hihan (The Wall of Cinema: A Critique of Storyism). Shinario 16: $84-87$.

Yoshihara, Junpei. 2011. Nihon tanpen eizōshi: Bunka eiga, kyōiku eiga, sangyō eiga (History of Japanese Short Films: Culture Films, Educational Films, Industry Films). Tokyo: Iwanami Shoten.

(C) 2020 by the authors. Licensee MDPI, Basel, Switzerland. This article is an open access article distributed under the terms and conditions of the Creative Commons Attribution (CC BY) license (http://creativecommons.org/licenses/by/4.0/). 